See discussions, stats, and author profiles for this publication at: https://www.researchgate.net/publication/275516135

\title{
Exploring Internet Addiction, Academic Procrastination and General Procrastination among Pre-Service ICT Teachers
}

Article · April 2014

DOI: $10.13054 /$ mije.14.18.4.1

\section{CITATIONS}

3

3 authors, including:

Ahmet Murat Uzun

Afyon Kocatepe University

16 PUBLICATIONS 23 CITATIONS

SEE PROFILE
READS

859

Erhan Ünal

Afyon Kocatepe University

13 PUBLICATIONS 16 CITATIONS

SEE PROFILE

Some of the authors of this publication are also working on these related projects:

Service teachers' academic achievements in online distance education: The roles of online self-regulation and attitudes View project 


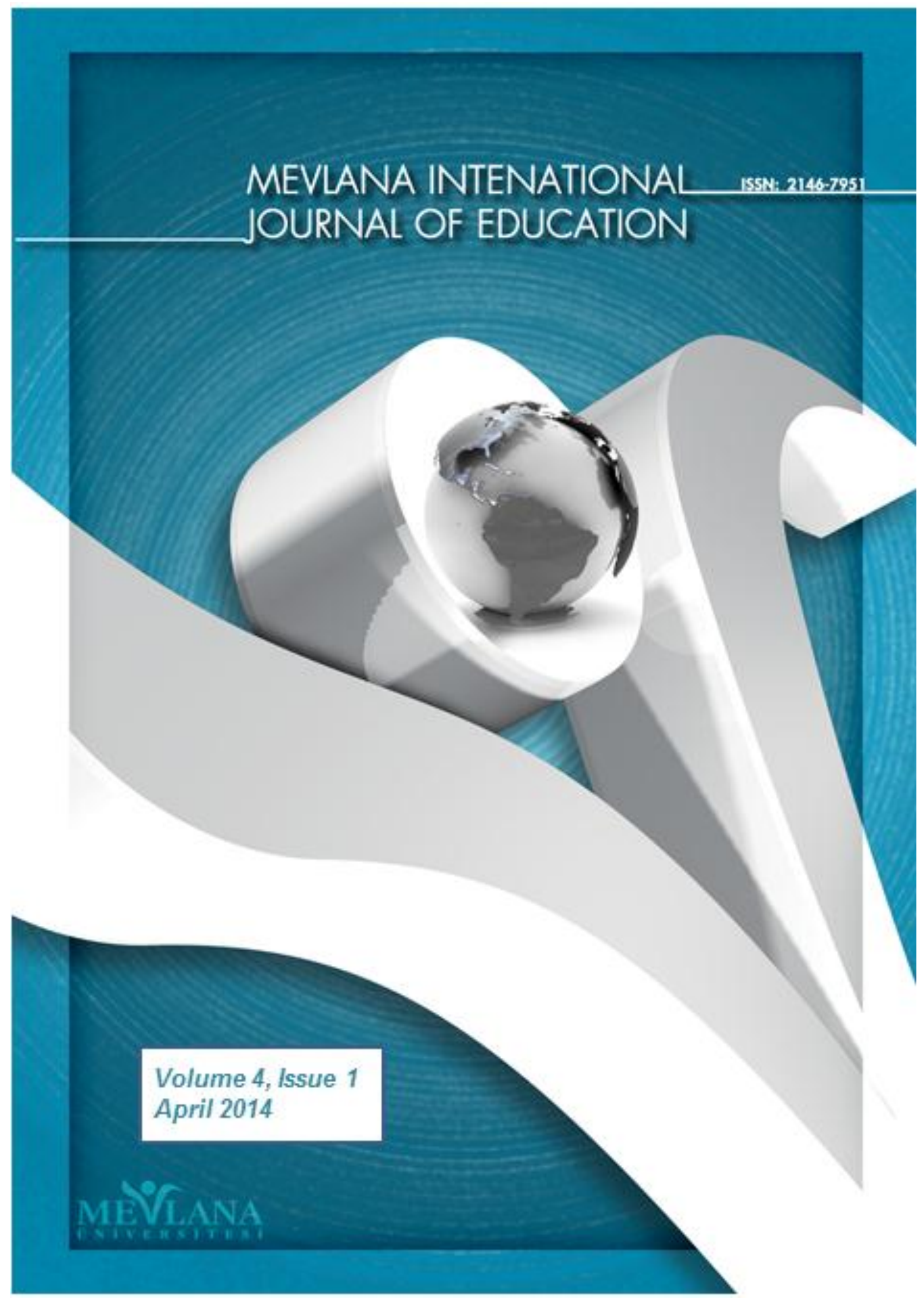




\section{Mevlana Intenational Journal of Education (MIJE)}

Volume 4, Issure 1

April 2014

MIJE is indexed in Turkish Educational Index, ASOS index, Index Copernicus, EBSCO Pub, Educational Research Abstracts (ERA), Aniji, DOAJ, Directory of Research Journals Indexing (DRJI) and ERIC (Published articles in MIJE are indexed by ERIC which is accepted by ERIC reviewers. Articles which are indexed by ERIC indicated in the table of contents in relevant issue) 
OWNER

\author{
ADAM, Bahattin \\ (Rector of Mevlana University) \\ EDITOR IN CHIEF \\ ÇELIK, Vehbi \\ (Dean of Education Faculty) \\ EDITOR \\ KORKMAZ, Özgen \\ ASSOCIATE EDITORS \\ NEL, Norma \\ LETSEKA, Moeketsi \\ SAMUEL, Mihael Anthony \\ ASSISTANT EDITOR \\ Durmuş, Alpaslam \\ KAYA, Sinan
}

SECRETARIAT OF THE JOURNAL

TOZKOPARAN, Süleyman, Burak

\title{
EDITORIAL BOARD
}

ABADIANO, Helen R. (Central Connecticut State University, USA) DEREVENSKY, Jeffrey L. (McGill University, Canada) AGAYEV, Ejder (Qafqaz University, Azerbaijan) DIBOLL, Mike (University of Sussex, UK)

AKBAŞ, Oktay (Kırıkkale University, Turkey) DOĞRU, S. Sunay Yıldırım(Dokuz Eylül University, Turkey)

AKKOYUNLU, Buket (Hacettepe University, Turkey) ECIRLI, Ahmet (Universiteti Bedër, Albania

AKMAN, Berrin Hacettepe University, Turkey ERBAY, Filiz (Mevlana University, Turkey)

AKPINAR, Burhan (Fırat University, Turkey) ERGÜN, Mustafa (Afyon Kocatepe University, Turkey)

AKPINAR, Yavuz (Boğaziçi University, Turkey) FALLAHI, Vida (Shiraz University, Iran )

AKTÜMEN, Muharrem (Ahi Evran University, Turkey) GAO, Ping (University of Northern lowa, USA)

AKYOL, Hayati (Gazi University, Turkey) GÖMLEKSiZ, Mehmet Nuri (Fırat University, Turkey)

ALACACl, Cengiz (Florida International University, USA) GÜNDÜZ, Mustafa (Yıldız Teknik University, Turkey)

AL-MABUK, Rathi (University of Northernlowa, USA) GÜNEL, Murat (TED, Turkey)

Anastasiadou, Sofia D. (University of West Macedonia, Greece) GÜROL, Mehmet (Yıldız Technical University, Turkey)

ARICIOĞLU, Ahu (Pamukkale University, Turkey) GURSEL, Musa (Mevlana University, Turkey)

BAEZZAT, Fereshteh (University of Mazandaran, Iran) GÜZELLER, Cem Oktay (Akdeniz University, Turkey)

BALOĞLU, Nuri (Ahi Evran University) HALAT, Erdoğan (Afyon Kocatepe University, Turkey)

BAYRAM, Servet (Marmara University, Turkey) HALAI, Nelofer(Aga Khan University, Pakistan)

BECK, Mitchell (Central Connecticut State University, USA) HAMMOND, John (University of Canberra, Australia)

BiLGiN, Ibrahim (Mustafa Kemal University, Turkey) HARPUTLU, Leyla (Ahi Evran University, Turkey)

BIRGiN, Osman (Uşak University, Turkey) HERRING, Mary C. (University of Northern lowa, USA)

BOOYSE, Johan (University of South Africa, South Africa) HOSSEINCHARI, Massound (Shiraz University, Iran )

BOZDOĞAN, Aykut Emre (Giresun University, Turkey) HUANG, Chi-Jen (National Chiayi University, Taiwan)

BOZOĞLAN, Bahadır (Mevlana University, Turkey) HUTSON, Bryant (The University of North Carolina a, USA)

BÜYÜKÖZTÜRK, Şener (Gazi University, Turkey) işçioĞLU, Ersin (Eastern Mediterranean University, TRNC)

ÇAKIR, Abdulkadir (Mevlana University, Turkey) IŞIK, Erkan (Mevlana University, Turkey)

ÇAKIR, Recep (Amasya University, Turkey) iŞMAN, Aytekin (Sakarya University, Turkey)

ÇANKAYA, Ibrahim (Uşak University, Turkey) KARA, Ahmet (Adıyaman University, Turkey)

ÇELIK, Vehbi (Mevlana University, Turkey) KARADAĞ, Ruhan (Adıyaman University, Turkey)

CHUANG, Hsueh-hua (National Sun Yat-sen University, Tayvan) KARADENiZ, Şirin (Bahçeşehir University, Turkey)

ÇOŞKUN, Eyyup (Mustafa Kemal University, Turkey) KARAMI, Morteza(University of Mazandaran, Iran)

DANIŞMAN, Yusuf (Mevlana University, Turkey) KARAKUŞ, Mehmet (Zirve University, Turkey)

DEMIREAY, Uğur (Anadolu University, Turkey) KARAMI, Morteza (University of Mazandaran, Iran)

DEMIREL, Şener (Fırat University, Turkey) KARATAŞ, Serçin (Gazi University, Turkey)

DEMIRLi, Cihat (İstanbul Ticaret University, Turkey) KARIM, Rezaul (Leading University, Bangladesh) 
KAUR, Kirandeep (Punjabi university, India) PING-KWAN, Fok (The Chinese University of Hong Kong)

KAYA, Osman Nafiz (Firat University, Turkey) POTGIETER, Calvyn (University of South Africa, South Africa) KESER, Hafize (Ankara University, Turkey) QUADIR, Tarik (Mevlana University, Turkey)

KOCABAŞ, İbrahim (Fırat University, Turkey) RANA, Rizwan Akram (University of the Punjab, Pakistan) KOÇAK, Recep (Gazi Osman Paşa University, Turkey) SADEGHI, Abbas (University of Guilan Iran)

KUMARAN, Duraikkannu (University of Madras, India) SAMUEL, Michael (University of Kwazulu-Nata, South Africa) LAVICZA, Zsolt (Cambridge University, UK) ŞAHIN, İsmail (Selçuk University, Turkey)

LEBLANC, Raymond (University of Ottawa, Canada) ŞAHIN, Sami (Gazi University, Turkey)

LEMMER, Eleanor (University of South Africa, South Africa) SAMANI, Siamak (Islamic Azad University, Iran) LOUW, Gabriel (North-West University, South Africa) SARI, Mustafa (Mevlana University, Turkey) MCKEOWN, John A. G. (Mevlana University, Turkey) SEMERCi, Çetin (Fırat University, Turkey) MEMMEDOV, Behmen (Qafqaz University, Azerbaijan) ŞENAY, Hasan (Mevlana University, Turkey) MICHAIL, Kalogiannakis (University of Crete, Greece) SHAHIM, Sima (Shiraz University, Iran ) MITTAL, Shree Ram (University of Delhi, India) SHARRA, Steve(Michigan State University, USA) MOONSAMY, Sharon (University of the Witwatersrand, S.Africa) SHELLEY, Mack (lowa State University, USA) MSILA, Vuyisile (University of South Africa, South Africa) SÜNBÜL , Ali Murat(Selçuk University, Turkey) NAM, Jeonghee (Pusan National University, Korea) TABAKU, Elida (Universiteti Bedër, Albania) NEL, Norma (University of South Africa, South Africa) TAŞPINAR, Mehmet (Gazi University, Turkey) ODABAŞI, H. Ferhan (Anadolu University, Turkey) THOMPSON, Ann D. (lowa State University, USA) OKUYUCU, Cihan (Yıldız Technical University University, Turkey) TÖREMEN, Fatih (Zirve University, Turkey) ÖMEROĞLU, Esra (Gazi University, Turkey) Trotman, Wayne (Izmir Katip Çelebi University) OMRAN, Ebrahim Salehi (University of Mazandaran, Iran) TÜYSÜZ, Cengiz (Mustafa Kemal University, Turkey) ORAL, Behçet (Dicle University, Turkey) UZUNBOYLU, Hüseyin (Near East University, TRNC)

ÖZDEMIR, M. Soner (Kırıkkale University, Turkey) UZOGLU, Mustafa (Giresun University, Turkey) ÖZDEMIR, Selçuk (Gazi University, Turkey) URE, Omer (Mevlana University, Turkey) ÖZER, Bayram (Mustafa Kemal University, Turkey) YALÇIN, Paşa (Erzincan University, Turkey) PANDAY, Shefali (University of Mumbai, India) YALIN, H. İbrahim (Gazi University, Turkey) PAPE, Stephen J.(University of Florida, USA) YAMAN, Süleyman (Zonguldak Karaelmas University, Turkey) PEKER, Murat (Afyon Kocatepe, Turkey) YILMAZ, Ercan (Selçuk University, Turkey) GIJON PUERTA, José (Universidad de Granada, Spain) YÖRÜK, Sinan (Afyon Kocatepe University, Turkey)

\section{REVIEWER OF THE ISSUE}

Ahmet AKKAYA (Adıyaman University) Alpaslan DURMUŞ (Mevlana University) Atieh Khayat (Arkansas State University) Ayfer SAHIN (Ahi Evran University) Aykut Emre BOZDOĞAN (Giresun University) Ayşe Negiş IŞIK (Mevlana University) Barış KARAELMA (Gazi University) Bülent DiLMAÇ (Necmettin Erbakan University) Cemal KARAATA (Fatih University) Deniz DERYAKULU (Ankara University) Erkan IŞIK (Mevlana University) Ertuğrul USTA (Mevlana University) EunJin BANG (lowa State University) Gülay EKici (Gazi University) Hakan Akçay (Yıldız Technical University) Haldun VURAL (Mevlana University) Halil ibtahim ÇANKAYA (Usak University) Halil TURGUT (Sinop University) Hülya GÜVENÇ (Yeditepe University) Hüseyin Öz (Hacettepe University) İbrahim KURT (Mevlana University)

Illhan VARANK (Yıldız Technical University) ilker YILMAZ (Mevlana University) Mediha SARI (Çukurova University) )
Mehmet Barış HORZUM (Sakarya University)

Mehmet TURAN (FIrat University)

Mehmet ÜNLÜ (Marmara University)

Melih Derya GURER (Abant İzzet Baysal University)

Mimi LEEC - Seoul National University)

Murat DEMIRBAŞ (Kırıkkale University)

Mwebesa UMAR (Uganda Islamic University)

Niyazi ÖZER (İnönü University)

Ömer Tuğrul KARA (Çukurova University)

Özgen KORKMAZ (Mevlana University)

Rabia HOŞ (Zirve University)

Recep ÇAKIR (Amasya University)

Rıfat MiSER (Ankara University))

Rüştü YEŞiL (Ahi Evran University))

Scott TITSWORTH (Ohio University)

Semiral ÖNCÜ (Uludağ University)

Serçin KARATAŞ (Gazi University)

Shefali PANDYA (University) of Mumbai

Sinan KAYA (Mevlana University)

Turan ÇETIN (Gazi University))

Ufuk KARAKUŞ (Gazi University))

Yurdal DiKMENLi (Ahi Evran University)

Yüksel GÖKTAŞ (Atatürk University) 


\section{TABLE OF CONTENTS}

Geographic literacy perception scale (GLPS) validity and reliability study http://dx.doi.org/10.13054/mije.13.43.4.1

Yurdal Dikmenli $1-15$

What they think about democracy? Sample of 8th grade American and Turkish students http://dx.doi.org/10.13054/mije.13.65.4.1

Nihal Baloglu Ugurlu 16-29

A validity and reliability study of the Attitude Scale of Computer Programming Learning (ASCOPL) http://dx.doi.org/10.13054/mije.13.73.4.1

Özgen Korkmaz, Halis Altun $30-43$

The effectiveness of computer assisted instruction on vocabulary achievement http://dx.doi.org/10.13054/mije.13.77.4.1

Tutku Basoz, Feryal Cubukcu

An Investigation of Science Active Learning Strategy Use in Relation to Motivational Beliefs http://dx.doi.org/10.13054/mije.13.55.4.1

Yasemin Tas, Birgul Cakir

Investigating the Reasons Institutions of Higher Education in the USA and Canada Utilize Blended Learning http://dx.doi.org/10.13054/mije.13.68.4.1

Noah Kasraie, Ala Alahm. 67-81

The Attitudes of Primary School Pre-Service Teachers towards Cursive Handwriting http://dx.doi.org/10.13054/mije.13.83.4.1

Ruhan Karadă

High School Students' Stereotypic Images of Scientists in South Korea http://dx.doi.org/10.13054/mije.13.58.4.1

EunJin Bang, Sissy S. Wong, Tonya D. Jeffery 96-112

Clustering Analysis of Students' Attitudes Regarding Distance Education:

Case of Karadeniz Technical University

http://dx.doi.org/10.13054/mije.13.87.4.1

Ozcan Ozyurt

Geography Teacher Candidates' Perceptions of Geotourism http://dx.doi.org/10.13054/mije.13.86.4.1

Hilmi Demirkaya, Mustafa Sagdic, Ali Osman Kocalar 
Preservice Teachers' Preferences About Instructor Gender http://dx.doi.org/10.13054/mije.14.05.4.1

Senay Yapici.

Classroom Emotions Scale For Elementary School Students (Ces-Ess)

http://dx.doi.org/10.13054/mije.13.72.4.1

Ahmet Yamac

General Behaviours of Students with Poor Listening Skills or Who Do Not Listen To the Lectures According To the Teachers' Opinions

http://dx.doi.org/10.13054/mije.14.03.4.1

Selim Emiroglu.

164-175

Factors Influencing Assessment Practices among University Academic Staff: A Multiple Regression Analysis

http://dx.doi.org/10.13054/mije.13.57.4.1

Musa Matovu, Ainol Madziah Zubairi.

176-188

Exploring Internet Addiction, Academic Procrastination and General Procrastination among Pre-Service ICT Teachers

http://dx.doi.org/10.13054/mije.14.18.4.1

Ahmet Murat Uzun, Erhan Unal, Saniye Tugba Tokel

189-201

Computer versus Paper-Based Reading: A Case Study in English Language Teaching Context http://dx.doi.org/10.13054/mije.13.78.4.1

Ekrem Solak.

The Relationship between the Achievement Goal Orientation and the Self Efficacy

Beliefs of the Candidate Teachers

http://dx.doi.org/10.13054/mije.13.76.4.1

Nese Ozkal, Vesile Yildiz Demirtas, Hale Kasap Sucuoglu, Cem Oktay Guzeller .....

The Views of Students and Teachers about using Fun-based Videos in English Language

Teaching (ELT)

http://dx.doi.org/10.13054/mije.13.84.4.1

Veli Batdi

The Use of Blogs in Learning English as a Foreign Language

http://dx.doi.org/10.13054/mije.13.79.4.1

Selami Aydin....

244-259

Perceived Social Support from Family, Participation in Recreational Sport Activities, Leisure Negotiation and Life Satisfaction in University Students

http://dx.doi.org/10.13054/mije.13.82.4.1

Evren Tercan 


\title{
Exploring Internet Addiction, Academic Procrastination and General Procrastination among Pre-Service ICT Teachers
}

\author{
Ahmet Murat Uzun* \\ Computer Education and Instructional Technology, Afyon Kocatepe University, \\ Afyonkarahisar, Turkey \\ Erhan Unal \\ Computer Education and Instructional Technology, Afyon Kocatepe University, \\ Afyonkarahisar, Turkey
}

Saniye Tugba Tokel

Computer Education and Instructional Technology, Middle East Technical University, Ankara, Turkey

\begin{tabular}{|c|c|}
\hline Article history & le with \\
\hline $\begin{array}{l}\text { Received: } \\
06.02 .2014\end{array}$ & $\begin{array}{l}\text { potential sociological effects. Considering this reality in mind, the } \\
\text { purpose of this research is to investigate the existence of internet }\end{array}$ \\
\hline $\begin{array}{l}\text { Received in revised form: } \\
18.03 .2014\end{array}$ & $\begin{array}{l}\text { addiction among pre-service ICT teachers. The study also aimed at } \\
\text { examining relationships among academic procrastination, general }\end{array}$ \\
\hline $\begin{array}{l}\text { Accepted: } \\
21.03 .2014\end{array}$ & $\begin{array}{l}\text { procrastination and internet addiction. Internet Addiction Test } \\
\text { (IAT), General or Life Routine Procrastination Scale (GP) and }\end{array}$ \\
\hline Key words: & \\
\hline $\begin{array}{l}\text { Pre-service ICT teachers, } \\
\text { academic procrastination, } \\
\text { general procrastination, internet } \\
\text { addiction }\end{array}$ & $\begin{array}{l}\text { tools. Adopting survey model, } 194 \text { pre service IC T teachers, } \\
\text { studying at one of the public universities in Turkey, participated to } \\
\text { the study. The results indicated that (1) internet addiction existed } \\
\text { among pre-service ICT teachers; (2) there were significant } \\
\text { relationships among the variables of academic procrastination, } \\
\text { general procrastination and internet addiction, and finally (3) } \\
\text { general procrastination was found to be a better predictor than } \\
\text { academic procrastination in predicting internet addiction. The } \\
\text { findings of the study were discussed in the lights of the literature } \\
\text { on internet addiction, general procrastination and academic } \\
\text { procrastination. }\end{array}$ \\
\hline
\end{tabular}

\section{Introduction}

Recently a survey on Information and Communication Technology Usage indicated that computer and internet use on households and individuals increased dramatically in Turkey. By 2013, the proportion of regular internet usage among individuals aged between 16 and 74 was found to be $39.5 \%$ (Turkstat, 2013). Likewise, in USA, a recent survey on internet use revealed that $86 \%$ of American adult users use internet actively. Based on the 
2011 survey, $74 \%$ of the internet users go online for no specific purpose, just for having fun or killing time (Pew Internet, 2013). Such high adoption rates could be attributed to the new possibilities provided by the internet which has the potential to get, create and distribute knowledge easily. To an extent, it is obvious that internet has many benefits for the students. On the other hand, the internet might have also detrimental effects on students if it is not used properly (Yang \& Tung, 2007; Odaci, 2011). In this sense, Davis (2001) made a distinction between the terms of healthy and unhealthy internet use. Healthy internet use refers to using internet for a specific purpose and a reasonable period of time. Contrary to this, unhealthy internet use refers to spending abnormal amounts of time in a pathological way in the internet with having no specific purposes. This kind of internet use is regarded to be as a psychological issue with potential sociological effects. For example, people who overuse the internet believe that internet is the only place where they feel themselves in a state of wellbeing. In addition, these people are preoccupied with internet while they are offline, expect more online time and spend excessive amount of money for internet related activities (Davis, 2001).

Many people find themselves on the internet as surfing while they should be working or studying on a specific task (Lavoie \& Pychyl, 2001). These people put off their work or academic related responsibilities and spend excessive amount of time on the internet (Davis, 2001). This kind of behavior was regarded as modern type of procrastination mediated by the internet in most of the research (Lavoie \& Pychyl, 2001; Davis, 2001; Thatcher, Wretschko \& Fridjhon, 2008). Studies showed that both internet addiction and procrastination are so common among college students (Solomon \& Rothblum, 1984; Lay, 1986 ; Yang \& Tung, 2007, Tice \& Baumeister, 1997; Kandell, 1998). However there are not many studies focusing on the internet addiction and its relation to procrastination among college students who belong to Information and Communication Technology related departments. Using computer related technologies more than the others; such departments may be more vulnerable to internet addiction and procrastination. Given this situation, the purpose of this research study is to examine pre-service ICT teachers' internet addiction levels and its relation to two procrastination measures which are defined as academic procrastination and general procrastination.

\section{Literature review}

\section{Internet Addiction}

The term "internet addiction" has been described in the literature with a variety of terms such as "pathological internet use" (Davis, 2001), "problematic internet use" (Caplan, 2010) and "internet addiction" (Young, 1998). For the current study, the term "internet addiction" was used which was regarded as the most popular one (Byun et al., 2009). Also in the literature no standard definition was provided for internet addiction. However there is a consensus among the researchers that the phenomenon exists (Chou, Condron \& Belland, 2005). According to Kandell (1998), internet addiction is "a psychological dependence on the internet, regardless of the type of activity once logged on" (p. 12). In addition to this view, one school of thought asserted that it is also important to consider the activities performed on internet as well as the amount of the time spent on the internet (Davis, 2001; Caplan, 2010). As Griffiths (1998) stated, "excessive use of the Internet may not be problematic in most cases but the limited case study evidence suggests that for some individuals, excessive Internet use is a real addiction and of genuine concern" (p. 73).

Stern (1999) stated that although technology increases our capacity and makes life easier, 
excessive and abuse of it may influence our life negatively. The literature showed that negative outcomes of the internet were discussed widely (Thatcher et al., 2008; Caplan, 2010; Young, 1996). In a review research article on internet addiction Chou et al. (2005) examined frequent problems caused by internet addiction and found that most of heavy internet users suffered from poor time management skills while using the internet. Distractors of the internet environment, deficient self-regulation mechanisms and poor time management skills may cause individuals to use internet as a way to postpone their responsibilities (Lavoie \& Pychyl, 2001; Davis, 2001).

\section{Procrastination}

The literature provides various definitions of procrastination all of which includes delay or postpone of a task or a goal (Ferrari, Johnson \& McCown, 1995; Lay, 1986). Generally Lay defined procrastination as "putting off of that which is necessary to reach some goal" (p. 475). In addition, procrastination has been regarded as the inconsistency between one's intention to act and actual performance of that act (Blunt \& Pychyl, 2005).

Most of the literature on procrastination research argued that the procrastination is a complex phenomenon that includes emotional, cognitive, and behavioral aspects (Fee \& Tangney, 2000). The behavioral tradition asserts that procrastination is a learned behavior. Reinforcement theory of behavioral tradition tries to explain the procrastination within the reward and punishment context. That is, procrastination occurs more in students if they are rewarded by pleasing activities for such behavior (Ferrari et al., 1995). Psychodynamic theory regards procrastination as symptoms of underlying conflicts that exist in subconscious and defense mechanism to avoid from those conflicts (Rückert, 2008). Cognitive-behavioral approaches argued that there are various factors explaining procrastination process. Irrational perfectionism, irrational beliefs, self-criticism, anxiety, depression, low self-esteem, learned helplessness and self-control are some of cognitive- behavioral aspects of procrastination discussed in the literature (Ferrari et al., 1995; Çakıc1, 2003). Although various definitions of different types of procrastination could be made, most of the literature on procrastination is grouped under the two major headings, which are "situational procrastination" and "trait procrastination" (Ferrari \& Scher, 2000). According to situational procrastination, people usually tend to procrastinate in order to avoid tasks that they find unpleasant or too difficult (Ferrari et al., 1995). Situational procrastination occurs dependently on the nature and context of a task and is related with certain parts of one's life. Academic procrastination which is widely discussed in literature is a sub form of situational procrastination (Çakıc1, 2003; Odac1, 2011; Solomon \& Rothblum, 1984). Generally, college students tend to perform their academic responsibilities that must be completed within the desired time interval. However, they mostly fail to do so (Ferrari et al., 1995; Lay, 1986; Solomon \& Rothblum, 1984).

Trait procrastination is defined as people's predispositions to delay or postpone tasks (Milgram, Mey-Tal \& Levison, 1998; Çakıc1, 2003). That is, unlike academic procrastination, trait or dispositional procrastination is not related with characteristics of the situation or the task. Instead, trait procrastination occurs depending on the personality traits of the individuals who continuously and chronically procrastinate (Ferrari et al., 1995). General or life routine procrastination is regarded to be a sub dimension of trait procrastination which is defined as "experienced difficulty in scheduling when to do the many recurring life routines and in doing them on schedule" (Milgram et al., 1998, p.276). In the literature, procrastination is more viewed as a generalized personality trait rather than being situational (Milgram et al, 1998). For instance, Ferrari and Scher (2000) found that students suffered more frequently from general or life routine procrastination than academic procrastination. Furthermore, in the 
literature, some of the researchers (Atkinson, Atkinson, Smith \& Bem, 1990) argued that both personality traits and situational factors may have roles in explaining procrastination. Overall, it may be concluded from the literature that both academic and general procrastination may have deleterious effects on one's intra- and inter-personal functioning (Milgram et al., 1998; Ferrari et al., 1995).

\section{Purpose of the study}

Procrastination is thought to be associated with academic failure and health problems among college students (Tice \& Baumeister, 1997). Dysfunctional use of internet is also regarded as a cause of physical, psychological and other problems which draw college students' attention away from their studies (Yang \& Tung, 2007). Bearing this fact in mind, it is hypothesized that procrastination could be linked with internet addiction. The literature provides little evidence regarding the relationship between internet addiction and procrastination (Odaci, 2011; Thatcher et al., 2008; Davis, 2001; Lavoie \& Pychyl, 2001). Besides, most of the studies were conducted with general college students' population. Specifically, this study dealt with the college students who were studying Information and Communication Technology. Those students are using computer related technologies in their everyday lives to carry out their projects. With this in mind, college students who are studying ICT are predicted to be vulnerable to internet addiction and procrastination. For this reason, research is needed to clarify the internet addiction and procrastinating behaviors for such departments. The results of the current study will make a significant contribution to our understandings about the prevalence of internet addiction and procrastination behaviors among pre service ICT teachers which will in turn make possible to diagnose the disease and take necessary precautions to protect students from negative effects of the internet.

Considering the literature given above, the aim of the current study is to examine the status of internet addiction and it's relation to academic and general procrastination for pre-service ICT teachers. The following research questions were proposed:

- What are the internet addiction levels of pre-service ICT teachers with respect to demographics?

- Do two measures of procrastination (academic procrastination and general procrastination) correlate with internet addiction for pre-service ICT teachers?

- How well do two measures of procrastination (academic procrastination and general procrastination) predict internet addiction for pre-service ICT teachers?

\section{Method}

\section{Participants}

The research group consisted of 194 pre-service teachers studying ICT (Computer Education and Instructional Technologies) at one public university located in Turkey. $48 \%$ of the group was female and 52\% of the group was male. The age of group ranged from 17 to 33. All students reported that they used internet frequently. As can be seen from the Figure 1, of all students, $66 \%$ of the students used internet for more than 5 years, $23 \%$ of the students used it for 3-5 years, $8 \%$ of the students used for 1-3 years and $4 \%$ of the students used internet for less than 1 year. 


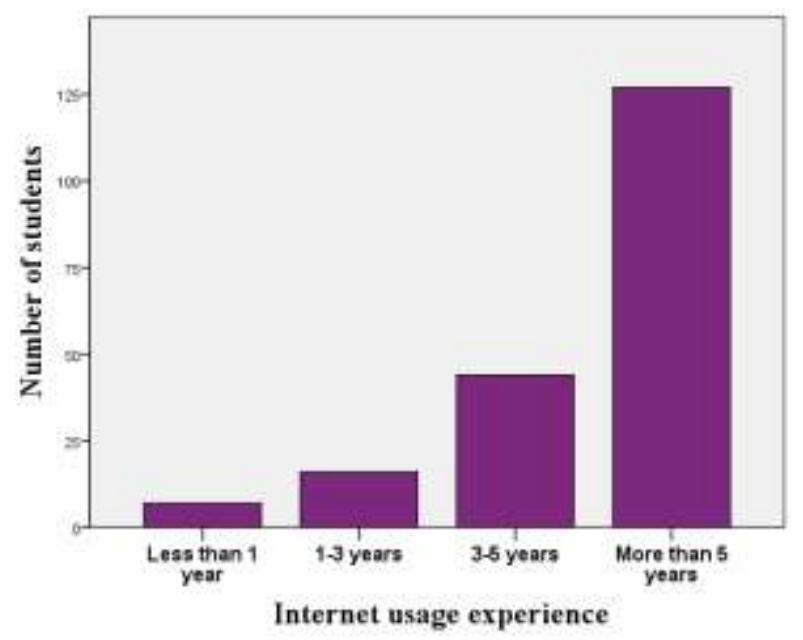

Figure 1 Internet usage experiences of students

Furthermore, $15 \%$ of the students reported that they use internet for 4-8 hours, $61 \%$ of the students use internet for 1-4 hours and $24 \%$ of them reported that they use internet for less than 1 hour in a day (see Figure 2).

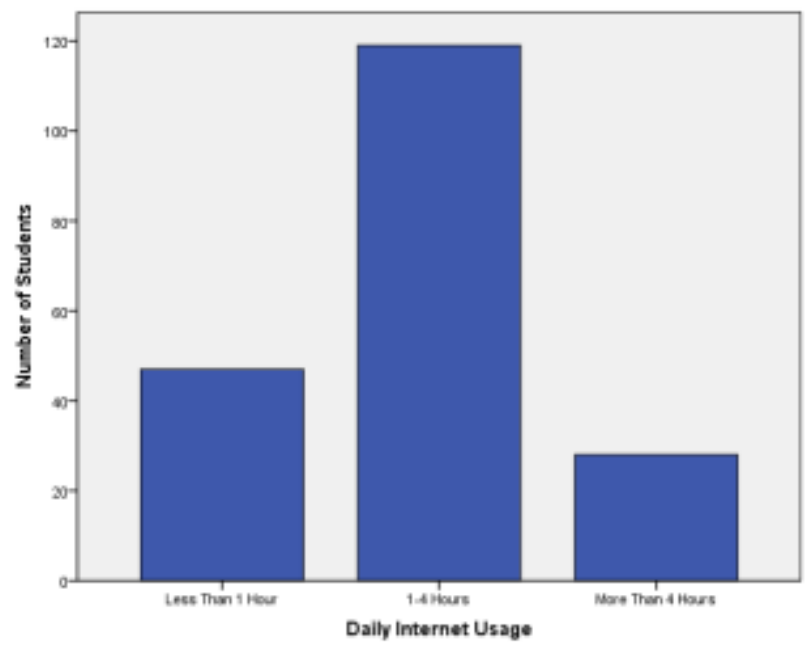

Figure 2 the amount of daily internet usage

\section{Data gathering tools}

Internet Addiction Test (IAT), General or Life Routine Procrastination Scale and Academic Procrastination Scale were used as data gathering tools. A personal information form was also used to collect data regarding demographics. The form consisted of variables such as age, gender, grade level, internet usage experience and daily internet usage.

\section{Internet Addiction Test (IAT)}

Internet Addiction Test was developed by Young (1998) and adapted into Turkish culture by Bayraktar (2001). IAT is a 20-item questionnaire that measures individual's levels of Internet Addiction. Each question was rated on six points likert type items. The items were scored as $0,1,2,3,4$ and 5 respectively. Scores obtained from the test vary between 0 and 100. One who gets 39 points and below from the test is interpreted as average online user, 40 
to 69 points as being experienced occasional or frequent problems because of the Internet and one who gets 70 points and above from the test is classified as internet addicts. For the current study, the value of cronbach alpha was found to be .90 .

\section{General or Life Routine Procrastination Scale (GP)}

The scale which was developed by Cakici (2003) consisted of 18 items. Each item was rated on five points likert type scale ranging from 1 (totally not true for me) to 5 (totally true for me). Scores obtained from the test vary between 18 and 90 . The scale does not have normative cut off scores however, higher scores on the scale show tendency to procrastination. The reliability analysis showed that the scale is quite reliable with cronbach alpha coefficient value of .91 .

\section{Academic Procrastination Scale (AP)}

Academic Procrastination Scale was developed by Cakici (2003) to measure the levels of academic procrastination. The scale consisted of 19 questions. Each item was rated on five points likert type scale ranging from 1 (totally not true for me) to 5 (totally true for me). Scores obtained from the test vary between 19 and 95 . Higher scores obtained from the scale indicate higher tendency to procrastination. The alpha coefficient value of the scale was .92 .

\section{Data analysis}

The data were analyzed by using SPSS 18 (PASW Statistics 18). Descriptive analyses were used in order to reveal internet addiction levels of pre-service ICT teachers. Independent sample $t$ test was conducted to examine mean difference in IAT scores according to gender. One way ANOVA was used to explore mean differences IAT scores according to demographics. Correlation analysis was used to explore relationship between academic procrastination, general procrastination and internet addiction. Finally simultaneous multiple linear regression was used to assess how well two measures (academic procrastination and general procrastination) predict internet addiction for pre-service ICT teachers.

\section{Results}

\section{Internet addiction levels of pre-service ICT teachers with respect to demographics}

The results of the analysis indicated that Internet Addiction Test Scores (IAT) of preservice ICT teachers ranged from 3 to 84 points with a mean score of $M=27.89$ ( $S D=$ 14.25). Based on the Young's (1998) addiction criteria the majority of the pre-service ICT teachers $(84 \%)$ were classified as average internet users with a mean score of $M=23.22$ ( $S D$ $=9.21$ ). That is to say, most of the students may spend a bit too long time on the internet but they have control over their internet usage. Moreover, $14.4 \%$ of them were interpreted as potential or possible internet users who are experiencing occasional or frequent problems because of the internet $(M=50, S D=7.02)$. The remaining part of the group $(1.5 \%)$ was classified as heavy internet users (internet addicts) who are experiencing significant problems related to overuse of internet $(M=75.33, S D=7.57)$. Totally almost $16 \%$ of the group was identified as ones who are internet abusers. To examine gender differences in IAT scores, independent sample $\mathrm{t}$ test was conducted. The results indicated that $\mathrm{t}$ test was significant $t$ 
$(173.23)=3.67, p=.00$. IAT scores of boys $(M=31.32, S D=16.25)$ were greater than IAT scores of girls $(M=24.16, S D=10.57)$.

One-Way ANOVA was conducted to explore if students IAT scores differed significantly according to grade level, amount of daily time spent online (hours) and internet usage experience (years). The results indicated that IAT scores did not differ significantly with respect to grade level and internet usage experience (years) but differed significantly with respect to amount of daily time spent online as expected, $F(2,191)=7.37, p=.00$. Follow up Post Hoc tests were conducted to examine the pairwise mean difference. The Levene's test was significant $(p=.01, p<.05)$ indicating that variances were not homogenous across groups. Therefore Dunnett's C test was used as a method of pairwise mean comparison (Green \& Salkind, 2005). The test indicated that there was a significant mean difference between those who spent less than 1 hour on internet in a day $(M=23.34, S D=14.71)$ and those who spent more than 4 hours on the internet $(M=35.98, S D=18.37)$. On the other hand no significant mean difference was observed between those who spent less than 1 hour on internet in a day and those who spent 1 to 4 hours on the internet.

Table 1. Descriptive statistics according to demographics

\begin{tabular}{|c|c|c|c|c|}
\hline & & $\mathrm{N}$ & Mean & SD \\
\hline \multirow[t]{2}{*}{ Gender } & Female & 93 & 24.16 & 10.57 \\
\hline & Male & 101 & 31.32 & 16.25 \\
\hline \multirow[t]{4}{*}{ Grade Level } & Grade 1 & 53 & 28.63 & 18.02 \\
\hline & Grade 2 & 45 & 27.44 & 12.81 \\
\hline & Grade 3 & 51 & 26.52 & 11.40 \\
\hline & Grade 4 & 45 & 29.01 & 13.81 \\
\hline \multirow[t]{4}{*}{$\begin{array}{l}\text { Internet Usage } \\
\text { Experience }\end{array}$} & Less than 1 Year & 7 & 21.67 & 15.90 \\
\hline & 1-3 Years & 16 & 20.22 & 9.45 \\
\hline & 3-5 Years & 44 & 27.33 & 16.43 \\
\hline & $\begin{array}{l}\text { More Than } 5 \\
\text { Years }\end{array}$ & 127 & 29.40 & 13.57 \\
\hline \multirow[t]{3}{*}{$\begin{array}{l}\text { Daily Internet } \\
\text { Usage }\end{array}$} & Less than 1 Hour & 47 & 23.34 & 14.71 \\
\hline & 1-4 Hours & 119 & 27.78 & 12.11 \\
\hline & More than 4 Hours & 28 & 35.98 & 18.37 \\
\hline
\end{tabular}

\section{Correlation between academic procrastination, general procrastination and internet}

\section{addictions scores}

Pearson's product-moment correlation coefficients were computed among academic procrastination (AP), general procrastination (GP) and internet addiction test scores (IAT). The results of the correlation analysis were presented in Table 2.

Table 2. Correlations between academic procrastination (AP), general procrastination (GP) and internet addiction test scores (IAT) $(\mathrm{N}=194)$

\begin{tabular}{lccc}
\hline Variable & AP & GP & IAT \\
\hline AP & - & & \\
GP & $.60^{* *}$ & - & \\
IAT $p<.05, * * p<.01$. & $.39^{* * *}$ & $.45^{* *}$ & - \\
\hline
\end{tabular}


$\mathrm{AP}=$ Academic procrastination, $\mathrm{GP}=$ General procrastination, $\mathrm{IAT}=$ Internet Addiction Test Scores

As Table 2 indicated, all correlations are significant at $p<.01$ level. The strength of the correlation between IAT and AP $(r=.39)$ and IAT and GP $(r=.45)$ were medium (Cohen, 1988, pp. 79). Overall, it could be concluded from the analysis that higher levels of procrastination behaviors (academic and general) are linked with higher levels of Internet Addiction Test Scores.

\section{Prediction of internet addiction by academic procrastination and general}

\section{procrastination}

Multiple linear regression analysis was conducted to examine how well academic procrastination and general procrastination predict internet addiction. Preliminary analysis was conducted to ensure no violation of normality, linearity, homoscedasticity and multicollinearity. Since general procrastination and academic procrastination are similar concepts, the most significant problem in the study was possible multicollinearity in procrastination measures. Generally the unacceptably perfect correlations between two independent variables like value of .90 or greater could be interpreted as the signal of the multicollinearity. Also the tolerance value should be greater than .20 and VIF value should be lower than 5 in order not to violate multicollinearity assumption (Field, 2009). The coefficient table indicated that Tolerance and VIF values are .64 and 1.56 respectively which was interpreted as multicollinearity problem did not exist.

After preliminary analysis, simultaneous multiple regression analysis were performed. The results of the multiple linear regression analysis were shown in Table 3.

Table 3. Regression Analysis Summary for Procrastination Variables Predicting Pre-service ICT Teacher's Internet Addiction

\begin{tabular}{lcccccc}
\hline \multicolumn{1}{c}{ Variable } & $B$ & $S E B$ & $\beta$ & $t$ & $r_{s}$ & $\left(r_{s}\right)^{2}$ \\
\hline Academic procrastination (AP) & .33 & .14 & .19 & $2.33^{*}$ & .15 & .02 \\
General procrastination (GP) & .60 & .14 & .34 & $4.21^{*}$ & .27 & .07 \\
$R^{2}=.22(N=194)$ & & & & & &
\end{tabular}

Note. ${ }^{*} p<.05$.

The analysis showed that the regression model significantly explained the relationship between ICT Teacher's Internet Addiction Test Scores (IAT) and the linear combination of the Academic Procrastination (AP) and General Procrastination (GP), $R^{2}=.22, F(2,191)=27.36, p<.001$. Moreover, approximately $22 \%$ of variance in Internet Addiction Test Scores (IAT) can be accounted for by Academic Procrastination (AP) and General Procrastination (GP). Although both Academic Procrastination (AP) and General Procrastination (GP) significantly contributed to the prediction of Internet Addiction (IAT), General Procrastination (GP) received stronger beta weight than Academic Procrastination (AP). That is, General Procrastination (GP) is a better predictor than Academic Procrastination (AP) in predicting Internet Addiction Scores (IAT). The unique variance explained by Academic Procrastination and General Procrastination indexed by the squared structure coefficients were quite low accounting for $2 \%$ and $7 \%$ of the total variance respectively. 


\section{Discussion}

The current study aimed at examining internet addiction levels of pre-service ICT teachers. The study also focused on pre-service ICT teachers' procrastinatory behaviors (academic and general) and their relation to internet addiction. The findings of the study were that (1) internet addiction existed among pre-service ICT teachers; (2) there were significant correlations between academic procrastination and internet addiction and also were significant correlations between general procrastination and internet addiction; (3) academic procrastination and general procrastination explained a significant amount of variance in preservice ICT teachers' internet addiction scores.

\section{Internet addiction levels of pre-service ICT teachers}

The first aim of the study was to explore the status of internet addiction among preservice ICT teachers. Results indicated that internet addiction exists among pre-service ICT teachers. Over $\% 14$ of them identified themselves as possible internet users who have occasional or frequent problems associated with their internet usage. On the other hand, 1.5\% of the group was found to be heavy internet users who have serious internet related problems in their lives. Totally, almost $16 \%$ of pre-service ICT teachers seemed to have some problems related to their internet usage. The percentage of internet addicted users is relatively low compared to other studies in the literature (Morahan-Martin \& Schemacher, 2000; Ghassemzadeh, Shahraray \& Moradi, 2008). This is maybe due to the fact that different instruments, samples, context and culture were used in those studies. In addition, since the current study had a small sample size, it was not surprising to encounter such a low ratio. For example, in a recent study, Adiele and Olatokun (2014) found that the prevalence of heavy internet users was $3.3 \%$ among 1022 university adolescents. No matter what the sample size and the ratio were, it was found that internet addiction existed and was an issue of concern. Thus, the results of the study could be seen as remarkable and should be taken into consideration. In the current study, it was not surprising to find that males seemed to be at a higher risk of internet addiction than females. This finding was also supported by previous studies on internet addiction conducted around world (Chou \& Hsiao, 2000; Griffiths, 1998; Scherer, 1997; Morahan-Martin \& Schumacker, 2000; Ceyhan, 2008). Internet addiction levels of pre-service ICT teachers were examined based on their grade level. Before analysis, according to developmental theory, it was assumed that first grade students might be more vulnerable to pathological internet use because of having more leisure times than the other grades (DiNicola, 2004). However the study found no significant differences in internet addiction scores according to grade levels. Having found similar results, DiNicola (2004) argues that internet addiction is much more complex phenomenon than comparison of grade levels can provide.

In the current study, experience on internet usage was not found to be linked with internet addiction. On the other hand the amount of daily internet usage (hours) was a significant factor explaining internet addiction among pre- service ICT teachers. This finding is consisted with previous research on internet addiction and daily time spent online (Caplan, 2005; Davis, 2001). In short, the study suggested that regardless of experience on internet usage, higher levels of daily time spent online associated with higher levels of internet addiction for preservice ICT teachers. 


\section{Correlation between academic procrastination, general procrastination and internet}

\section{addictions scores}

The second aim of the study was to explore relationships between two measures of procrastination (academic procrastination and general procrastination) and internet addiction scores. The findings showed that there was a positive correlation between academic procrastination and internet addiction meaning that pre-service ICT teachers who procrastinate in their academic life also tend to use internet in a pathological manner. Although limited studies addressing academic procrastination have found no significant correlation between academic procrastination and internet addiction (Odac1, 2011), our study found that academic procrastination is significantly linked with internet addiction. Although this is a significant finding, it may also be attributed to the nature of the study group. That is, pre-service ICT teachers are hypothesized to use internet more frequently than the others in their daily lives.

The correlation between academic procrastination and internet addiction was also supported by the literature indirectly. For example Scherer (1997) concluded that "excessive internet use is problematic when it results in impaired functioning such as compromised grades or failure to fulfil responsibilities" (Scherer, 1997, p. 656). Kubey, Lavin, and Barrows (2001) found that academic grades of addicts were significantly lower than those of non-addicts.

This study also proved that there was a significant correlation between general procrastination and internet addiction. This finding suggested that ones who delay their life routine responsibilities also tend to be more vulnerable to be internet addicts. The previous research studies were also in the supposed direction. Deficient time management skills may result in students failing to fulfill their daily routine responsibilities which may have an influence on being dependent on the internet (Lin \& Tsai, 1999; Chou \& Hsiao, 2000).

\section{Prediction of internet addiction by academic procrastination and general}

\section{procrastination}

The third and last aim of the study was to explore the strength of the academic procrastination and general procrastination in predicting internet addiction. The findings indicated that academic procrastination and general procrastination together significantly predicted the degree of internet addiction among pre-service ICT teachers. In addition general procrastination was found to be a better predictor than academic procrastination. That is, students who perceived themselves as general procrastinators also tend to be more vulnerable to be internet addicts. In literature, two dominant forms of procrastination were discussed including trait and situational procrastination. As stated before, trait or dispositional procrastination is highly related with general or life routine procrastination (Çakıc1, 2003). That is, individuals who habitually procrastinate, delay their daily routine responsibilities. Likewise, academic procrastination is considered as a form of situational procrastination. Situational procrastination assumes that students tend to procrastinate if they find a specific task as unpleasant or too difficult (Ferrari et al., 1995). Our study found that general procrastination which is related to personality traits is a better predictor of internet addiction than academic procrastination which is related to situational or conditional factors. Hence, it may be concluded based on this finding that one's own personality traits may be more important than situational factors in explaining procrastination behaviors which may in turn have a predictive effect on explaining the levels of pre-service ICT teachers' internet addiction. There are limited studies in the literature exploring the strength of internet 
prediction by academic procrastination and general procrastination. However, as literature on procrastination research indicated, procrastination is thought to be more related to personality traits than situational factors (Milgram et al., 1998; Ferrari \& Scher, 2000) This may be an answer to the question of "why general procrastination (personality traits) is a better predictor than academic procrastination (situational procrastination)" in predicting the level of internet addiction among pre-service ICT teachers.

\section{Conclusion}

This study adds internet addiction literature by examining the relationship between procrastination behaviors and internet addiction for pre-service ICT teachers. Although, academic procrastination and general procrastination together explained a significant portion of variance in internet addiction, the unique variances explained by each of predictors were small. Nevertheless, considering the limited literature on internet addiction and procrastination behaviors for college students who belong to technology related departments, this study would be beneficial for school administrators to gain an insight about the status of internet addiction and procrastination among pre-service ICT teachers. Based on our understandings about internet addiction and its relation to procrastination, maybe it will be possible to detect the diseases at an early stage and take necessary precautions.

The present study has some limitations. First of all, since the study used correlational design, it did not provide causal relationship between procrastination and internet addiction. That is, the results of this study do not imply that procrastination causes internet addiction or vice versa. Further longitudinal studies are needed to explore causality among procrastination measures and internet addiction. Secondly, the generalizability of the results is restricted to the setting where data were gathered. In addition, findings are based on the qualities of selfreported measures used for the study. Further studies may explore causes and consequences of internet addiction and procrastination for pre-service ICT teachers with systematic analysis through in-depth interviews and observations. Thirdly, many different applications (online social networking, online shopping) exist in internet some of which may be hazardous. Therefore as Thatcher et al. (2008) suggested, further studies are needed to explore whether specific internet applications have an influence on internet addiction then the others.

\section{References}

Adiele, I., \& Olatokun, W. (2014). Prevalence and determinants of Internet addiction among adolescents. Computers in Human Behavior, 31, 100-110.

Atkinson, R. L., Atkinson, R. C., Smith, E. E., \& Bem. (1990). Personality theory and assessment. In introduction to psychology (10th ed.). San Diego, CA: Harcourt Brace Jovanovich.

Bayraktar, F. (2001). İnternet kullanımının ergen gelişimindeki rolü [The role of Internet use in adolescent development]. (Unpublished doctoral dissertation). Ege University, Izmir, Turkey.

Blunt, A., \& Pychyl, T. A. (2005). Project systems of procrastinators: A personal projectanalytic and action control perspective. Personality and Individual Differences, 38(8), 1771-1780.

Byun, S., Ruffini, C., Mills, J. E., Douglas, A. C., Niang, M., Stepchenkova, S., ... Atallah, M. (2009). Internet addiction: metasynthesis of 1996-2006 quantitative research. CyberPsychology \& Behavior, 12(2), 203-207. 
Caplan, S. E. (2005). A Social skill account of problematic internet use. Journal of Communication, 55(4), 721-736.

Caplan, S. E. (2010). Theory and measurement of generalized problematic Internet use: A two-step approach. Computers in Human Behavior, 26(5), 1089-1097.

Ceyhan, A. \& Aykut. (2008). Predictors of problematic internet use on Turkish university students. CyberPsychology \& Behavior, 11(3), 363-366.

Chou, C., Condron, L., \& Belland, J. C. (2005). A review of the research on Internet addiction. Educational Psychology Review, 17(4), 363-388.

Chou, C., \& Hsiao, M.-C. (2000). Internet addiction, usage, gratification, and pleasure experience: the Taiwan college students' case. Computers \& Education, 35(1), 65-80.

Cohen, J. W. (1988). Statistical power analysis for the behavioral sciences (2nd ed.). Hillsdale, NJ: Lawrence Erlbaum Associates.

Çakıcı, D. Ç. (2003). Lise ve Üniversite Öğrencilerinde Genel Erteleme ve Akademik Erteleme Davranışının Incelenmesi [An Examination of the general procrastination behavior and academic procrastination behavior in high-school and university students]. (Unpublished master's thesis). Ankara University, Ankara, Turkey.

Davis, R. A. (2001). A cognitive-behavioral model of pathological Internet use. Computers in Human Behavior, 17(2), 187-195.

DiNicola, M. D. (2004). Pathological Internet Use Among College Students: The Prevalance of Pathological Internet Use and Its Correlates (Unpublished doctoral dissertation). Ohio University.

Fee, R. L., \& Tangney, J. P. (2000). Procrastination: A means of avoiding shame or guilt? Journal of Social Behavior \& Personality.

Ferrari, J. R. (2000). Procrastination and attention: Factor analysis of attention deficit, boredomness, intelligence, self-esteem, and task delay frequencies. Journal of Social Behavior \& Personality.

Ferrari, J. R., Johnson, J. L., \& McCown, W. G. (1995). Procrastination and task avoidance: Theory, research, and treatment. Springer.

Ferrari, J. R., \& Scher, S. J. (2000). Toward an understanding of academic and nonacademic tasks procrastinated by students: The use of daily logs. Psychology in the Schools, $37(4), 359-366$.

Field, A. (2009). Discovering statistics using SPSS. Sage publications.

Ghassemzadeh, L., Shahraray, M., \& Moradi, A. (2008). Prevalence of Internet addiction and comparison of Internet addicts and non-addicts in Iranian high schools. CyberPsychology \& Behavior, 11(6), 731-733.

Green, S., \& Salkind, N. (2005). Using SPSS for Windows and Macintosh: Understanding and analysing data. Upper Saddle River, NJ: Prentice-Hall.

Griffiths, M. (1998). Internet addiction: does it really exist? In Gackenbach (Ed.), Psychology and the Internet: Intrapersonal, interpersonal, and transpersonal implications (pp. 61-75). San Diego, CA: Academic Press.

Griffiths, M. (2000). Internet addiction-time to be taken seriously? Addiction Research \& Theory, 8(5), 413-418.

Kandell, J. J. (1998). Internet addiction on campus: The vulnerability of college students. CyberPsychology \& Behavior, 1(1), 11-17.

Kubey, R. W., Lavin, M. J., \& Barrows, J. R. (2001). Internet use and collegiate academic performance decrements: Early findings. Journal of Communication, 51(2), 366-382.

Lavoie, J. A. A., \& Pychyl, T. A. (2001). Cyberslacking and the procrastination superhighway: A web-based survey of online procrastination, attitudes, and emotion. Social Science Computer Review, 19(4), 431-444. 
Lay, C. H. (1986). At last, my research article on procrastination. Journal of Research in Personality, 20(4), 474-495.

Li, H., Wang, J., \& Wang, L. (2009). A survey on the generalized problematic Internet use in Chinese college students and its relations to stressful life events and coping style. International Journal of Mental Health and Addiction, 7(2), 333-346.

Lin, S. S., \& Tsai, C.-C. (1999). Internet Addiction among High Schoolers in Taiwan. Poster presented at the American Psychology Association (APA) Annual Convention, Boston, USA.

Lin, S. S., \& Tsai, C.-C. (2002). Sensation seeking and internet dependence of Taiwanese high school adolescents. Computers in Human Behavior, 18(4), 411-426.

Milgram, N. N., Mey-Tal, G., \& Levison, Y. (1998). Procrastination, generalized or specific, in college students and their parents. Personality and Individual Differences, 25(2), 297-316.

Morahan-Martin, J., \& Schumacher, P. (2000). Incidence and correlates of pathological Internet use among college students. Computers in Human Behavior, 16(1), 13-29.

Odaci, H. (2011). Academic self-efficacy and academic procrastination as predictors of problematic internet use in university students. Computers \& Education, 57(1), 11091113.

Pew Internet \& American Life Project. (2003). Usage Over Time. Retrieved from http://fe01.pewinternet.org/Trend-Data-(Adults)/Usage-Over-Time.aspx

Rückert, H.-W. (2008). Procrastination: Loitering with intent will begin later. Retrieved from http://www.fu-

berlin.de/sites/studienberatung/team/hwr/dokumente/Procrastination_Leidenfinal2.pdf ?1307228249

Scherer, K. (1997). College life online: Healthy and unhealthy Internet use. Journal of College Student Development, 38(6), 655-665.

Solomon, L. J., \& Rothblum, E. D. (1984). Academic procrastination: Frequency and cognitive-behavioral correlates. Journal of Counseling Psychology, 31(4), 503-509.

Stern, S. E. (1999). Addiction to technologies: A social psychological perspective of Internet addiction. CyberPsychology \& Behavior, 2(5), 419-424.

Thatcher, A., Wretschko, G., \& Fridjhon, P. (2008). Online flow experiences, problematic Internet use and Internet procrastination. Including the Special Issue: Internet Empowerment, 24(5), 2236-2254.

Tice, D. M., \& Baumeister, R. F. (1997). Longitudinal study of procrastination, performance, stress, and health: The costs and benefits of dawdling. Psychological Science, 454 458.

TurkStat. (2013). Turkish Statistical Institute Information and Communication Technology (ICT) Usage Survey on Households and Individuals. Retrieved from http://www.turkstat.gov.tr/PreHaberBultenleri.do?id=13569

Yang, S. C., \& Tung, C.-J. (2007). Comparison of Internet addicts and non-addicts in Taiwanese high school. Computers in Human Behavior, 23(1), 79-96.

Young, K. S. (1996). Psychology of computer use: XL. Addictive use of the Internet: a case that breaks the stereotype. Psychological Reports, 79(3), 899-902.

Young, K. S. (1998). Caught in the net: How to recognize the signs of internet addiction--and a winning strategy for recovery. John Wiley \& Sons. 